\title{
NOTES
}

\section{THE EQUITY RECEIVERSHIP IN MASS TORT}

FIRE, explosion and other negligently precipitated disasters may force normally healthy businesses into virtual insolvency. ${ }^{1}$ The disaster may spawn enormous multiple tort claims which far exceed liability insurance coverage. Claimants will try to tie up surviving assets of the business by legal process, ${ }^{2}$ thus hampering business recovery. Corporate assets may be further bled by the expenses of defending claims. Each claim may have to be defended separately $;^{3}$ litigation may continue for years. A final obstacle to recovery arises when the claims reach judgment. Judgment creditors can then levy on the assets and force sale. ${ }^{4}$ When such execution is multiplied by large

1. A striking recent example is Irwin v. Willis, 202 Ga. 463, 43 S.E.2d 691 (1947) (hotel fire); see also, Slover v. Coal Creek Coal Co., 113 Tenn. 421, 82 S.W. 1131 (1904) (mine explosion).

2. This is ordinarily done by attaching the defendant's property. Usually this places the property in the possession of the attaching officer. See MOORE \& Countryman, DeBTORS' AND CREDitors' RigHTS 33-54 (1951). Where attachment is secured, the undestroyed earning assets of the business may be immediately tied up by personal injury claimants. The problem is particularly acute in the minority of jurisdictions that permit easy attachment. See, e.g., Conn. Gen. Stat. $\$ \$ 8022-3$ (1949); Me. Rev. Stat. c. $101, \S \S 1-3$ (1944) ; Mass. GEN. Laws c. 223 , $\S 16$ (1932) ; N.H. REv. Laws c. 386 , $\$ 4$ (1942) ; R.I. Gen. Laws cc. 546-7, (1938); VT. Rev. Stat. \$\$1522-9 (1947). In these states attachment is made by plaintiff's attorney acting as an officer of the court, or without any court intervention, and is normally part of the original service of process. See Comment, 38 Y ALE L.J. 376 (1929). The immediate difficulties are not as great in other jurisdictions where attachment is limited to specific situations and application must be made to a court for the writ. See, e.g., N.Y. Crv. Prac. Act 817, 902-11 (1946); Calif. CIv. Proc. and Prob. Codes $\$ \$ 537-61$ (1949). In these states a claimant can attach only where the defendant is a nonresident or, for some other reason, the court believes that his property may not later be available. See Sturges \& Cooper, Credit Administration and Wage Earner Bankruptcies, 42 YALE L.J. 487, 503-10 (1933).

Where attachment is unavailable, the defendant may transfer his property before judgment. Usually the only protection for the claimant-creditor in such a situation is the doctrine of Fraudulent Conveyances. See, e.g., Uniforar Fraudulent Conveyance ACr. For discussion of the doctrine at common law, and in statutes see MOORE \& Countryman, $o p$. cit. supra, at 165-254; Glenn, Fraudulent Conveyances and Preferences (rev. ed. 1940).

3. The doctrine of res judicata makes any single judgment binding only upon the two parties. Restatement, Judgements $\$ 93$ (1942). See also Note, 18 N.Y.U.L.Q. Rev. 565 (1941).

Most modern codes contain provision for permissive joinder of plaintiffs where there are common issues of law and fact to be determined. Clark, Code Pleading $\$ \$ 57,58$ (2d ed. 1947). However, this may not be practical when there are hundreds of plaintiffs.

4. For discussion of various methods of using the property of the debtor in satisfaction of judgment See GLENN op. cit. supra, note 2, at 8-71 (Rev. ed. 1940) ; James, Collections of Money Judgments in Conn. 14 Cons. B.J. 3-21 (1940). Of course, forced sale by unorganized creditors is bound to result in a lower return than if the assets were sold as an operating whole. 
numbers of creditors, the defendant will be well on the way toward total collapse, and claimants will fail to recover in full.

All of these problems threatened the Ringling Bros.-Barnum and Bailey Circus after its disastrous Hartford, Connecticut, fire in 1944.5 The fire killed or injured over 500 people and destroyed much key circus property. Most remaining property was quickly attached by the many tort claimants, ${ }^{\circ}$ forcing the circus to remain in Hartford. The circus was sued by over 500 claimants. With already crowded dockets, it might have taken courts ten years to process all claims. ${ }^{7}$ The business was at a standstill and the possibility of bankruptcy became real.

Faced with these threats to the solvency of an otherwise sound business, the Connecticut Superior Court, at the request of one of the tort claimants, placed the circus in the hands of a receiver. ${ }^{8}$ This put all of the Circus' property in Connecticut under the court's control and blocked any subsequent attachments. ${ }^{9}$ It also abated all previous attachments. ${ }^{10}$ Furthermore, under receivership court permission was required for all suits against the receiver. ${ }^{11}$

5. For a complete summary of the events surrounding the fire, see the Hartford Times, Aug. 23, 1950 p.1, col.1. See also the Hartford Courant July 7-17, 1944, p.1 of any included date.

6. Connecticut permits immediate attachment by plaintiff "upon all complaints containing a money demand against the estate of the defendant ..." CoNN. GEN. Stat. $\S \S 8022-3(1949)$.

7. This is the rough estimate of the attorney for the Receiver of the circus. The estimate is based on the assumption that one judge and jury can try approximately 40 ordinary cases in a year and that duplication of lawyers and doctors would further slow the process. In fact, the Connecticut jury docket was almost 3 years behind at the time of the fire. The ten year figure was arrived at after making an allowance for some settlements. Communication to the Yale Law Journal from Julius B. Schatz, Attorney for the Receiver of the Circus, dated Oct. 23, 1951, in Yale Law Library.

8. Jacobs Administrator v. Ringling Bros.-Barnum and Bailey Combined Shows Inc., Conn. Superior Court Docket No. 71519 (1944) (opinion not reported).

9. Receivership acts as a general moratorium upon creditor rights. And the receiver takes possession of the defendant's assets as an officer of the court. See 1 CIARK, Receivers 55, 332-68 (2d ed. 1929). See also Comment, 14 OkLA. B.J. 1618 (1943).

10. This could occur only in a minority of jurisdictions. In these states, receivership statutes avoid attachment liens acquired within a certain period before receivership. This is the rule in Connecticut. Conn. GEN. STAT. $\$ 8250$ (1949); In re Wilcox \& Howe Co., 70 Conn. 220, 39 Atl. 163 (1898). For similar provisions see Ala. Cope AnN. tit. 7 $\S 1167$ (1940); Me. Rev. Stat. c. $49 \S 101$ (1944) ; Mass. Gen. Laws c. $223 \$ \$ 130-1$ (1932); R.I. GeN. Laws c. $551 \$ 1$ (1938); WIs. Stat. $\S 128.18$ (1949). However in most states, the liens persist after the appointment of the receiver. HIGH, RECEIvERS $\S 138$ (4th ed. 1910).

11. Suits against the receiver must usually have court permission. Note, 48 A.L.R. 241 (1927). For the exception to this rule in Federal practice see Moore, Commentary oN THE U.S. Judictal CODE 296 (1949). But suits against the defendant himself may be prosecuted to judgment, Note, 8 A.L.R. 441 (1920), where only in personam judgment is desired, unless these suits interfere with the possession of the receiver. However judgments obtained thereby can only be satisfied by presenting them to the receiver since the normal creditors' remedies are abated. And the mere fact of a judgment does not always 
The receivership was accompanied by an arbitration agreement negotiated by the claimants and the circus. ${ }^{12}$ This agreement facilitated the processing and payment of claims. ${ }^{13}$ The circus waived any defenses of contributory negligence or lack of negligence. ${ }^{14}$ In return, the assets were released, thus permitting the circus to operate its business and pay the claims from current earnings until discharge. ${ }^{15}$ By December 1950, all of the claims were arbitrated

bind the receiver to pay the exact amount stated. Bank of Bethel v. Pahquioque Bank, 81 U.S. 383 (1871); see note, 8 A.L.R. 441 (1920). See Beach, Judgment Clains in Receivership Proceedings, 30 YaLE L.J. 674 (1921).

12. The arbitration agreement is on file in the Yale Law Library. For the statutory framework see Conn. Gen. STAT. $\$ \$ 8151-77$ (1949). A summary of statutory provisions in other jurisdictions may be found in KeLlor, Arbitration In Action 217-346 (1941).

The arbitration was pushed through by realistic cooperation between the receivership group, the circus group, the Hartford County Bar Association and the court. Public opinion in Hartford and the fear that the Connecticut court, which strongly favored the arbitration device, would look with disfavor upon non-agreement claimants strongly influenced acceptance of the arbitration by most claimants.

13. All of the arbitration hearings were completed within 3 years. Communication to the YALE LAw JouRNAL, supra note 7. They were heard by a three man arbitration panel chosen by the parties and the court. "[I]nsofar as practicable . . . formal rules of evidence. . . " did not govern. ARbitration Agreenrent 2(E). (hereinafter cited as AGREEMENT) In addition, the arbitrators were given power to call in their own experts and "investigating assistants." AGREement 2(j). This streamlined method disposed of 692 claims in short order. 112 of these were under $\$ 200$. 35 claims were disallowed. Therefore 551 major awards were made. Of these 169 were death cases.

14. The "cause of action" set up under the agreement was simple. The Circus waived "any and all defense it may have [had] on the question of liability. ..." AGREERIENT 1. "[T]he only questions to be arbitrated [were] (1) the actual receipt of damage to person and/or property at the scene of the ... fire, and (2) the monetary amount of said damage to the person and/or property." Ibid.

The award of the arbitration panel was final. The only appeal allowed lay when a party claimed an award to be "defective in regard to an obvious miscalculation, clerical error, identity of parties or that the arbitrators ... passed upon a matter not submitted to them...." Even here, the appeal could be directed only to the arbitrators. Ibid.

The arbitration panel was to control any substantial settlements made between the Circus and claimants. The Circus was allowed to settle any cases not exceeding $\$ 200$. Agreement $2(Q)$. Many small claims were settled in this way, Communication to the YALE LAW Journal, supra note 7, but any settlements in excess of this sum had to be "submitted to the arbitrators for their approval. ..." AGREEMSENT 2(Q). If the arbitrators refused to approve such settlement they were to "call for the production of such additional evidence by either one or both of the parties or their own independent investigators and medical experts as they ... deem[ed] necessary in order to establish (1) the existence of such claim, and (2) the amount of damages to be awarded." Id. at $2(\mathrm{P})$.

The Circus waived the Statute of Limitations as a defense to signatories of the agreement but retained it as a defense to nonsignatories. Id. at 10 . In addition the Circus was required to "resist vigorously" any claims brought by claimants outside the arbitration agreement. Id. at 12. And the expense of defending such suits was to be considered an operating expense of the Circus. Ibid. See note 15 infra.

15. The claims were to be paid in periodic dividends from the income of the Circus after it returned to operation and from other sums due the Circus in income tax refunds, and proceeds of insurance policies. Id. at 6. The Hartford County Bar Asso- 
and total payments exceeding $\$ 3,900,000$ had been made to all claimants through the receiver. ${ }^{16}$

The use of a receivership in this maner is somewhat unusual. ${ }^{17}$ Had there been a challenge in the Ringling Bros. case, ${ }^{18}$ two traditional barriers might have blocked the receivership. First, a tort claimant, like all non-judgment creditors, has no standing in equity to ask for a general receivership. ${ }^{19}$ Second, courts are reluctant to allow receivership solely for "moratorium purposes."20

ciation was authorized to audit the Circus books yearly to ascertain that dividend standards were being observed. Id. at 8 . In return, the Circus agreed "to file no voluntary petition in bankruptcy...." Id. at 6 . If the Circus were involuntarily adjudicated a bankrupt or became "insolvent" ("in determining any such insolvency, the claims of the claimants shall not be included....") or sought "reorganization under Chapter 10 of the Bankruptcy Act. ..." then any party to [the] agreement ... [was] . . free to pursue any and all remedies at law or in equity." Ibid.

16. N.Y. Times December 10, 1950 p. 44, col. 5.

17. The Georgia Supreme Court approved the use of a somewhat similar receivership for tort claimants whose actions arose from a disastrous fire in the Winecoff Hotel in Atlanta. See Geele v. Willis, $203 \mathrm{Ga} .267$, 46 S.E.2d 126 (1948). For the earlier cases in the same litigation in which receivership was initially denied, see Irwin v. Griffin, 202 Ga. 466, 43 S.E.2d 687 (1947) ; Irwin v. Willis, 202 Ga. 463, 43 S.E.2d 691 (1947). For a heated discussion of the cases, see Molnar, Equity Jurisdiction in Torts, 10 GA. B.J. 309 (1948). This is the only other recent recorded use of the equity receivership for nonjudgment tort claimants.

18. None of the parties in interest challenged the receiver. Such challenge might have come from the Circus, Pusey \& Jones Co. v. Hanssen, 261 U.S. 491 (1923); a creditor, Lumbermans Bank v. Lake Shore Machinery Co., 260 Mich. 440, 245 N.W. 494 (1932) ; or possibly even a stockholder, Hoiles v. Watkins, 117 Ohio St. 165, 157 N.E. 557, 61 A.L.R. 1203 (1927); but see Cole v. Seaman, 266 Fed. 846 (8th Cir. 1920) ("Where . . . no question of . . . good faith, ... stockholders cannot interfere. . .."). The Circus would have been in the best position to object since it could defend on the merits as well as on jurisdictional grounds. However as a practical matter, the Circus was unlikely to object because the debtor will usually want the receivership. Creditors and stockholders may challenge where there is fraud, Shapiro v. Wilgus, 287 U.S. 348 (1932) ; or lack of jurisdiction, Lumbermans Bank v. Lake Shore Machinery Co., supra. For general discussion of the procedural problems involved in upsetting receiverships, see Comment, 47 Yale L.J. 746 (1938).

The receivership might have been challenged indirectly if a creditor petitioned for involuntary bankruptcy. The appointment of the receiver constituted an act of bankruptcy, 52 SтAт. 844-5 (1938), 11 U.S.C. $\$ 21$ (a) (5) (1946); and the bankruptcy trustee would take over from the receiver 52 STAT. 844 (1938), 11 U.S.C. $\$ 11$ (a) (21) (1946). But no claimants or creditors ever raised this point since the receivership enabled the Circus to pay all claims in full. Bankruptcy proceedings of course rarely result in full recovery.

19. 1 Clark, Receivers 210-12 (2d ed. 1929); See Note, 109 A.L.R. 2391 (1937). For a collection of cases involving the application of this doctrine to tort claimants, see Note, 4 A.L.R. $2 d 1278$ (1949).

20. 1 Clark, Recervers 60 (2d ed. 1929). A leading Supreme Court statement is found in Michigan v. Michigan Trust Co., 286 U.S. 334, 345 (1932). See also Note, 84 A.I.R. 1443,1459 (1933). 
The doctrine that only lien or judgment creditors may compel receivership is followed in most jurisdictions. ${ }^{21}$ This rule is based on the old division between law and equity and rooted in the idea that a non-judgment creditor has not yet pursued his remedy at law and therefore cannot seek equitable relief. ${ }^{22}$ Furthermore, courts have been reluctant to apply a remedy which deprives parties of jury trials in disputed claims. ${ }^{23}$ And an underlying fear exists that nuisance claimants will use the threat of receivership to coerce the defendant into making a favorable settlement. ${ }^{24}$

Similarly, courts have been reluctant to sanction receiverships designed solely to impose a moratorium upon the rights of creditors. The orthodox doctrine is that the appointment of a receiver is not an equitable action in itself; rather it must be ancillary to the "ultimate remedy" sought from the court. ${ }^{25}$ Since a moratorium receivership only delays the claims of creditors and does not provide other remedies, it fails to meet this requirement. ${ }^{26}$ This attitude has been reinforced by the ease with which debtors could induce a friendly non-judgment creditor to force receivership at a time which would best suit management and favored creditors. ${ }^{27}$ Since receivership normally

21. 1 CIARK, RECEIvers 210-47 (2d ed. 1929). For a typical and authoritative expression see Pusey \& Jones Co. v. Hanssen, 261 U.S. 491, 497 (1923).

22. 1 Ciark, Receivers 210-11 (2d ed. 1929); Higm, Recenvers $\$ 301$ (4th ed. 1910). See Pusey \& Jones v. Hanssen, 261 U.S. 491, 497 (1923).

23. 1 CiARK, Recetvers $210-20$ (2d ed. 1929). The reluctance is usually expressed when a non-judgment creditor files a creditor's bill-a proceeding preliminary to receivership. Scott v. Neely, 140 U.S. 106 (1890).

24. The courts fear that persons with dubious claims will force settlement by threatening to tie up the defendant's assets in a receivership proceeding. See e.g. Royal Academy of Beauty Culture v. Wallace, 226 Ind. 383, 389, 78 N.E.2d 32, 34 (1948); Slover v. Coal Creek Coal Co., 113 Tenn. 421, 431, 82 S.W. 1131, 33 (1904) for typical expressions of this fear.

25. 1 Clark, Receivers 58-62 (2d ed. 1929). For a recent Supreme Court statement of the doctrine, see Kelleam v. Md. Casualty Co., 312 U.S. 377 (1941). But cf. Scattergood v. American Pipe \& Construction Co., 247 Fed. 712 (E.D. Pa. 1917), aff'd, 249 Fed. 23 (3d Cir. 1918).

26. Typical remedies for which a receivership has been held ancillary are: MortgageForeclosure, Lincoln Joint Stock Land Bank v. Bundt, 234 Iowa 1011, 14 N.W.2d 865 (1944); Partition of Real Estate, Lent v. H. C. Morris, 25 Cal. App. 2d 305, 77 P.2d 301 (1938); Specific Performance, Lewis v. Independence Hotels Co., 153 Kan. 678, 113 P.2d 149 (1941); Equitable Attachment, Aetna Ins. Co. v. Robertson, 126 Miss. 387, 88 So. 883 (1921); Dissolution of Trust, Melville v. Weybrew, 106 Colo. 121, 103 P.2d 7 (1940); Fraudulent Conveyance, $\$ 10$ UnIForM Fraudulent ConveYance ACT; Injunction, Fulton Land Co. v. Armour Insulating Co., 192 Ga. 526, 15 S.E.2d 848 (1941). See 4 Pomeroy, Equity Jurisprudence 923-32 (5th ed. 1941).

27. For the ease of obtaining friendly receiverships see Douglas \& Weir, Equity Receiverships In the District Coutrt For Conn. 4 Cons. B.J. 1, 3 (1930) (38 out of 44 receivers "were of a friendly nature"). The judicial attitude is forcefully stated in Michigan v. Michigan Trust Co., 286 U.S. 334 (1932). See also Shapiro v. Wilgus, 287 U.S. 348 (1932) ; Hardy v. North Butte Mining Co., 20 F.2d 967 (D. Mont. 1927). For an extensive study and report on the entire subject of reorganization receiverships see, SEC, Report on the Study and Investigation of the Work, Activities, Personnel and Functions Of Protectrve And Reorganization Comamittees (1936-40). 
prevents attachments and executions upon liens or property in the hands of the receiver, ${ }^{28}$ the rights of other creditors would be delayed. A further justification for this attitude is that receivership without reorganization or liquidation in view cannot remedy the normally long-run financial imbalances which characterize most business difficulties. ${ }^{29}$ Thus such a receivership serves merely to delay the honest claims of creditors.

The policies behind these doctrinal restrictions are not flouted by the application of a receivership in disaster situations. Mass tort necessitates a special procedure for the orderly disposition of claims and assets- the primary purpose of any receivership. ${ }^{30}$ Since the defendant in a disaster situation will want receivership, the use of the receivership as a coercive device need not be feared. Nor is the lack of jury trial necessarily prejudicial to claimants. ${ }^{31}$ An arbitration agreement can be evolved by claimant committees under judicial supervision. ${ }^{32}$ Absent arbitration, the defendant might be sued as an individual and the judgments presented to the receiver for payment in an orderly manner. And if defendant is basically financially sound, a temporary moratorium would provide a breathing spell in which to adjust to an essentially abberational drain. Creditors' rights would be protected rather than impaired.

As a doctrinal matter, the major difficulty in the use of the receivership is in making the jump from judgment to non-judgment creditors as parties with standing to obtain the relief. The bars are almost entirely judicial in origin. $^{33}$ Statutory handicaps are rare. ${ }^{34}$ Some courts have already made a

28. See note 9 supra.

29. 2 Dewing, Financial Policy of Corporations 1271-81 (4th ed. 1946).

30. This has been the traditional purpose of the receivership device. 1 Crark, Recervers 15 (2d ed. 1929). See Ex parte Goodwyn, 227 Ala. 173, 149 So. 216 (1933); Commercial Banking \& Trust Co. v. Doddridge County Bank, 118 W.Va. 37, 188 S.E. 663 (1936).

31. Liquidation of tort claims arising out of pre-receivership accidents may be effected in one of three ways. A claim may be proven with the receiver, and a jury trial foregone. Suits commenced before the receivership may be prosecuted to completion. And in some jurisdictions, the receiver himself may be sued with leave of court and the case tried to a jury.

Liquidation of tort claims rising out of accidents occuring during the receivership may be effected either by proving the claim to the receiver or instituting a suit at law against the receiver with court permission. In the federal courts such leave is not required. See note 11 supra. See Underhay, Tort Claims In Receivership, 22 Iowa L. Rev. 60 (1936).

32. The proposal for arbitration of claims as an adjunct to receivership presents a pattern familiar to many lawyers. Formal arbitration merely institutionalizes and supervises the negotiations of creditors committees in typical reorganization receiverships. See SEC REPORT. supra, note 27.

33. See notes 19-24 supra.

34. In 16 states with substantially the same statutes, the type of creditors who may institute receivership proceedings is not specified. Receivers may be appointed "[i]n ... cases where a corporation has been dissolved, or is insolvent, or in imminent danger of insolvency. ..." These statutes also allow receivers "[i]n all . . . cases where receivers have heretofore been appointed by usages of courts of equity." CALIF. Cone CIv. Proc. §56 (1949); Idaho Code Anv. § 8-601 (1949); Ind. Stat. Ann. § 3-2601 (Burns Repl. 
limited exception to the rule by allowing simple contract creditors to institute receivership proceedings where defendant consents or admits liability to the claim. ${ }^{35}$ And courts of three states, including Connecticut, have sustained appointment of receivers for non-judgment creditors even against the challenge

1946); Kan. Gen. Stat. c. 60, $\$ 1201$ (1949); Mont. Rev. Code $\$ 93-4401$ (1947) ; Nev. Comp. Law AnN. $\$ 8749$ (1929) ; N.D. Rev. Code $\$ 32-1001$ (1943); OHIo Gen. Code Anv. $\$ 11894$ (1938); OkLa. Stars. Ann. tit. 12, 1551 (1937); Ore. Comp. Laws Ann. $\$ 15-502$ (1940) ; S.C. Code ANn. $\$ 584$ (1942) ; S.D. Code $\$ 37.2601$ (1939); TEx. Civ. Stat. art. 2293 (Vernon 1950) ; Utar Crv. Code \$104-20-1 (1943); Wash. Rev. Stat. Ann. tit. 5, $\$ 741$ (1932); Wis. Stat. \$268.16 (1949); Wyo. Coms. Stat. Ann. 3-7301 (1945).

Most of the other state statutes are similar in their failure to require judgment creditor status for receivership of an insolvent corporation. ALA. CoDE ANN. tit. 10, \$106 (1940) ("any number of creditors or stockholders. . . .); ARIz. CODE ANN. 22-301 (1939) ("when no other adequate remedy is given by law for the protection and preservation of property, or the rights of the parties. ..."); ARK. STAT. ANN. tit. 36-101 (1947) ("any creditor or stockholder of any insolvent corporation. ..."); DEI. REv. CoDE $\$ 4407$ (1935) ("any creditor or stockholder. . . .) ; GA. CoDE ANN. \$55-305 (1947) ("where there is manifest danger of loss, or destruction. ...") ; IrL. ANN. Stats. c. 32, §157.87 (1935) ("ordinary powers of a court of equity. . . .); Iowa CoDE ANw. $\$ 491.66$ (1949) ("on good cause shown. . . .); Ky. Rev. Stat. ANN. \$271.555 (1948) ("usual powers of a court of equity. ..."); ME. REv. Stat. c. 49 \$100 (1944) ("through attachment, litigation, or otherwise, its estate and effects are in danger of being wasted or lost . . . upon application of any creditor or stockholder. ..."); MIss. Cone $\$ 5355$ (1942) ("any creditor. . . ") ; NEb. Rev. Stat. \$25-1081 (1948) ("in all . . cases where receivers have heretofore been appointed by the usages of courts of equity.") ; N.J. STAT. ANN. \$14-14-3 (1939) ("any creditor or stockholder. ..."); N.M. Stat. ANN. \$ 54-603 (1941) ("any creditor or stockholder. ..."); PA. Stat. ANN. tit. $39 \$ \$ 31(7), 33$ (1930) ("any creditor. ...") ; R.I. GEN. Laws c. 116, §57 (1938) ("any stockholder or creditor. ..."); TENN. CODE ANN. $\$ 10364-5$ (Williams 1934) ("the creditors of a corporation may ... without first having obtained judgment at law. ...") ; W.VA. CoDE $\$ 3094$ (1949) ("upon sufficient cause ... a creditor, stockholder or member. . . .").

Eight states however seem to require judgment creditor status to obtain a statutory receivership. Colo. Stat. ANN. c. 41, §69 (1935); La. Rev. Stat. R.S. 12 :752 (1950) (this statute however provides for statutory consent receivership); Mass. GEs. LAwS AnN. c. 156, §51 (1951); Mich. Stat. AnN. \$27.2396 (Callaghan 1943 Rev.); MrnN. Stat. Ann. $\$ 301.50$ (West 1945); Mo. Rev. Stat. Ann. $\$ 4997.88$ (Cum. Supp. 1943) (provision for consent); N.Y. Gen. CoRp. LAw § 150; N.C. Gen. Stat. Ann. §1-502 (1943).

Six states have no limiting statufes. They are Connecticut, Florida, Maryland, New Hampshire, Virginia, and Vermont.

35. See e.g., $R e$ Metropolitan Railway Receivership, 208 U.S. 90 (1908) ; Greenbaum v. Lehrenkrauss Corp., 73 F.2d 285 (2d Cir. 1934) ; Herman C. Miller Co. v. Silvers Mffg. Co., 227 Iowa 1060, 289 N.W.699 (1940); Globe Solvents, Inc. v. Nouskhajian, 148 Pa. Super. 202, 24 A.2d 687 (1942) ; Contra: National Lumberman's Bank v. Lake Shore Machinery Co., 260 Mich. 440, 245 N.W. 494 (1932).

The theory of "consent" receivership is that the court has jurisdiction of the parties and of the subject matter and that "consent" is merely waiver by defendant of his right to insist upon plaintiff exhausting his legal remedies. The jurisdictions that do not allow "consent" receivership interpret the problem as one of "jurisdiction" which can never be waived. See Hill, Consent Receiverships in Federal Equity Practice, 11 CHI-KENT L. 
of defendant. ${ }^{36}$ The elimination of the division between law and equity should make the restrictive doctrine obsolete in all jurisdictions.

Similar flexibility has characterized the attitude of some legislatures and courts toward receiverships for the purpose of moratorium. Some jurisdictions by statute permit personal receiverships as an alternative to bankruptcy. ${ }^{\mathbf{3 7}}$ Under these plans, a wage earner debtor is granted a moratorium on garnishment and attachment by creditors. Furthermore, some courts have been liberal in finding an "ultimate remedy" to which the receivership may be ancillary. Thus, the reorganization receivership developed under the fiction that liquidation was the ultimate remedy, since reorganization itself was not considered sufficient. $^{38}$ One state court has upheld the use of a receivership instituted

REv. 267 (1933); Clark, Simple Contract Creditor Securing Appointment of Receiver, 1 Untv. of Cinn. L. Rev. 388 (1927) ; 31 Mich. L. Rev. 1001 (1933). See also Moore \& Countryman, op. cit. supra note 2 , c. 10.

However the "consent receivership" doctrine does not extend to allow "consent receivers" for individuals as distinguished from corporations. Fleet v. Hooker, 178 Okla. 640, 63 P.2d 988, 109 A.L.R. 272 (1936). But this rule may not apply to partnerships. See Globe Solvents, Inc. v. Nouskhajian, 148 Pa. Super 202, 24 A.2d 687 (1942).

36. Vail v. Hammond, 60 Conn. 374, 22 Atl. 954 (1891) (the elimination of the division between law and equity said to allow receivership for non-judgment creditors); Feeney Hay Co. v. Trenton Milling Co., 189 Ga. 109, 5 S.E.2d 235 (1939) ("facts sufficient to justify a court in its discretion to grant the extraordinary relief ... [of] . . an injunction and receiver. ..."); Wright v. Steenman, 254 Ky. 381, 71 S.W.2d 991 (1934) (insolvency-receivership "best and last resort ..."). Some other states have reasoned that the elimination of the division between law and equity allows non-judgment creditors to bring creditors bills; e.g., First Nat. Bank v. McDonough, 19 Ariz. 223, 168 Pac. 635 (1917); Simonton v. Simonton, 33 Idaho 255, 193 Pac. 386 (1920); Wofford-Fain Co. v. Hampton, 173 N.C. 686, 92 S.E. 612 (1917); Miller v. Hughes, 33 S.C. 530, 12 S.E. 419 (1890). In these cases, receivership was not sought. Other states have interpreted their receivership statutes to allow receivership at the behest of non-judgment creditors; Leydan v. Calhoun Co-op Creamery Co., 223 Ala. 289, 135 So. 317 (1931); Smith v. Solomon Valley Dredging Co., 147 Wash. 69, 264 Pac. 1009 (1928).

37. The theory is that given a stay, the wage earner can eventually repay his creditors in full by periodic dividends. An important illustration of this type of provision is the Wage Earner Plan of the Bankrutcy Act. 52 Stat. 930-8 (1938), 11 U.S.C. $\$ \S 1001-86$ (1946). See discussion in Moore, Bankruptcx Manual 756-9 (1st ed. 1939). For further discussion see Comment, 46 YALE L.J. 1177, 1190 (1937). The problems leading to the passage of the plan and some thoughtful early proposals are discussed in Douglas, Wage Earner Bankruptcies-State vs. Federal Control, 42 YaLE L. J. 591 (1933) and Sturges \& Cooper, Credit Administration and Wage Earner Bankruptcies, 42 Yale L.J. 487 (1933). For similar state programs see Mrch. Stat. ANN. 27.2441-53 (1943); Ohro Gen. Code §11728-1 (1938) Wrs. Stat. 128.21 (1949). These are discussed in Garrison, Wisconsin's New "Personal Receivership" Law, [1938] WIs. L. Rev. 201; Note 6 U. of CHr. L. Rev. 459 (1939); Douglas, supra.

38. See Burton v. R. G. Peters Salt \& Lumber Co., 190 Fed. 262, 265 (W.D. Mich. 1911); American Brake S. \& F. Co., v. Pere Marquette R. Co., 205 Fed. 14, 18-20, 24 (6th Cir. 1913). For further discussion, see Finletter, Principles of Corporate Reorgantzatton c. 1 (1937); Rohritch, Law and Practice in Corporate Control c. 7 (1933). For a probing insight into the fiction of "liquidation," see ARNOLD, THE Foliglore of Capitalism 235-41 (1st ed. 1937). 
solely to prevent the lending of money by defendant corporation at usurious interest rates. ${ }^{39}$ And there is even a line of cases sustaining operating moratorium receivership on the grounds that public welfare demanded the services of defendant corporation. ${ }^{40}$

When the solvency of a corporation is threatened by multiple tort claims arising out of an aberrational accident, the lead of the Connecticut court should be followed. Absence of this remedy would force the defendant into either bankruptcy or reorganization. Under the former, the recovery of the tort claimants at best will only be partial. ${ }^{41}$ Under the latter, a structurally healthy business will have to undergo financial surgery-under the circumstances, a wasteful procedure. On the other hand, receivership solved the major problems in the Ringling Bros. case. It acted initially as a stay upon creditor activity directed at the circus assets. It facilitated the processing and payment of claims. Thus it was the major factor enabling the circus to regain solvency, and satisfy the just claims of the injured.

39. State ex rel. Goff v. O'Neil, 205 Minn. 366, 286 N.W. 316 (1939) (state acquired lien on usurious interest payments by statute and thus had standing as a lien creditor), noted, 7 U. of CHr. L. Rev. 177 (1939); cf. Columbian Athletic Club v. State ex rel. McMahan, 143 Ind. 98, 40 N.E. 914 (1895) (receivership adopted to abate a public nuisance); Contra: State ex rel. Claude v. District Court, 204 Minn. 415, 283 N.W. 738 (1939) (same facts but receivership void because obtained $c x$ parte), noted, 23 MINs. L. REv. 843 (1938).

40. E.g. Scattergood v. American Pipe \& Construction Co., 247 Fed. 712 (E.D. Pa. 1917); Quincy, M. \& P. R. Co., v. Humphreys, 145 U.S. 82, 101 (1892); Brassey v. New York \& N. E. R. Co., 19 Fed. 663-6 (D. Conn. 1884). See Re Metropolitan Railway Receivership, 208 U.S. 90, 112 (1908). For discussions of the influence of public policy considerations upon the granting of receivership see First National Bank v. Flershem, 290 U.S. 504, 15 (1934) ; New England Coal \& Coke Co. v. Rutland R. Co., 143 F.2d 179, 184 (2d Cir. 1944).

41. Tort claimants who did not commence their suits before the appointment of a trustee receive nothing out of the bankrupt's estate, since such claims will not be "provable" in bankruptcy. 52 STAT. 873 (1938), 11 U.S.C. \$103 (1946). 